\title{
Impact of Remittance on Consumption and Savings Behavior in Rural Areas of Bangladesh
}

\author{
Mohammed Ziaul Haider ${ }^{a^{*}}$, Tanbir Hossain ${ }^{b}$, Ohidul Islam Siddiqui ${ }^{c}$ \\ a Professor, Economics Discipline, Khulna University, Khulna-9208, Bangladesh, Phone: +88-017-3000-4131 \\ b Lecturer, North Western University, Khulna, Bangladesh, E-mail: shovon_09ku@yahoo.com \\ c Professor, ISRT, University of Dhaka, Dhaka, Bangladesh, Phone: +88-017-4615-3344, E-mail: ohid1234@yahoo.com \\ ${ }^{*}$ Corresponding author's email address: haidermz@yahoo.com
}

\section{A R T I C LE IN F O}

Received: 27-07-2016

Accepted: 26-08-2016

Available online: 29-09-2016

Keywords:

Consumption;

Household;

Remittance;

Rural Bangladesh.

JEL Classification:
D10; E21; F24; 018

\begin{abstract}
A B S T R A C T
This study measures the impact of remittance on consumption and savings behavior though surveying rural households in Bangladesh. It uses hypothesis testing to compare consumption and savings behavior and path model analysis to trace out the impact of remittance on household level consumption and savings behavior in rural areas of Bangladesh. The remittance receiver households receive US\$ 358 monthly remittance on an average. The average monthly food expenditure, aggregate expenditure and savings of a remittance receiver household are about US \$28, \$32 and $\$ 10$ higher than that of a non-receiver household. The path model analysis findings indicate that remittance has a statistically significant positive impact on attributing food and aggregate consumption expenditure in addition to savings. Therefore, this study concludes that remittance plays an important role in attributing consumption and savings behavior in the selected rural areas of the south-west region of Bangladesh. However, further study addressing randomness in the sample selection process with wider sample and study area coverage might enhance the robustness of the study findings.
\end{abstract}

This is an open access article under the terms of the Creative Commons Attribution License 4.0, which allows use, distribution and reproduction in any medium, provided the original work is properly cited.

DOI: http://dx.doi.org/10.18533/job.v1i4.49

ISSN: 2380-4041(Print), 2380-405X(Online)

\subsection{Introduction}

Migration is a usual phenomenon among the countries all over the world. Generally, people choose overseas migration for better job and livelihood. The migrants contribute to economic development of their home countries through sending remittances. According to UO (2012), the rate of growth in remittance was 10.24 per cent in FY 2011-2012, which is 4.21 per cent higher than that of FY 2010-2011. Bangladesh received US\$12.84 billion remittances in FY 2011-2012, which is 1.21 billion more than that of FY 2010-2011 (BBS, 2011). Such remittance is an important source of fund to meet immediate needs of the migrants' families in their home countries covering food, health and education-related consumption expenditures in addition to savings (IFAD, 2007, as cited in Parinduri \& Thangavelu, 2008).

Remittance is a widely addressed issue in the literature. It is an important indicator which is linked with exchange rate, employment, investment, growth and GDP. Chowdhury, Hamid and Chatterjee (2010) focus on the impact of remittance on various economic indicators of a country. Udah (2011) focuses on the links among remittance, human capital and economic performance of Nigeria. Mellyn (2003) discusses the role of workers' remittances in Philippine economy. Adams, Cuecuecha, and Page (2008) illustrate the linkages among remittance, consumption and investment in Ghana. Ghosh (2006) postulates the relationship of remittance with 
development. El-Sakka (2004) shows the relationship between migrant workers' remittance and macroeconomic policy in Jordan. Hasan (2004) also shows the relationship among remittance and macroeconomic determinants. Barajas, Chami, Fullenkamp, Gapen, and Montiel (2009) describe the economic growth process through remittance. Bruyn and Kuddus (2005) find that remittance inflow and its proper utilization can influence social development of a country.

Remittance has the influencing tool for poverty alleviation and consumption-smoothing effect on migrants' household. Sinning (2008) highlights on the determinants of savings and remittance from Germany perspective. Adams and Cuecuecha (2010) narrate the utilization of remittance on household's expenditure and investment in Guatemala. Castaldo and Reilly (2007) demonstrate the effect of remittance on the consumption pattern of Albanian households. Osili (2006) identifies a relationship between savings and remittance from migration. Parinduri and Thaegavelu (2008) describe the effect of remittance on migrant household's consumption and saving pattern from Indonesian perspective.

Like many other countries, remittance plays an important role in Bangladesh economy. More than 6.7 million people have migrated from Bangladesh to more than 140 countries since mid-1970s. Remittance accounted for more than 12 per cent of GDP in 2010 having colossal socio-economic implications for the country (Siddiqui, 2004). Mamun and Nath (2010) show the influences of remittance on macroeconomic performance of Bangladesh economy. Kabir, Rashid, Hossain, Rashid, and Amin (2011) also highlight on the contribution of remittance in Bangladesh economy. Ahmed and Uddin (2009) find that growth of remittance increases the export earnings of the country. Azad (2003) also illustrates the importance of migrants' remittance in Bangladesh economy. Workers' remittances have an ever important role as one of the major sources of foreign exchange earnings for Bangladesh economy. Barua, Majumder, and Akhtaruzzaman (2005) explore the macroeconomic determinants of inflow of workers' remittances in the context of Bangladesh. Beaudouin (2006) shows the positive impact of migration on the development of rural areas in Bangladesh.

Therefore, it is evident that a bunch of studies on remittance are available in the literature, from Bangladesh as well as other country perspectives. However, a specific study addressing the consumption and savings behavior of remittance receiving households in rural Bangladesh are hardly available in the literature. Most of the available studies address the remittance issue from macro perspectives considering country-level macro data. The evidence of household level studies using primary level micro data is scarce from Bangladesh perspective. Moreover, there is a little evidence in the literature for addressing the impact of remittance on household level consumption and saving behavior using primary data for rural areas of Bangladesh. Therefore, this study attempts to fill the said gaps.

This study attempts to collect household level primary data through administering questionnaire survey for addressing the said research gap. It uses hypothesis testing to compare consumption and savings behavior and path model analysis to trace out the impact of remittance on household level consumption and savings behavior in rural areas of Bangladesh, which are the main objectives of this study. This section briefly describes the background of the study along with review of important literature to identify research gap. Second section demonstrates the materials and methods of the study. Section three reports the results and discussion. Finally, section four includes concluding remarks.

\subsection{Materials and methods}

The main objective of this study is to compare the consumption and savings behavior between remittance receiver and non-receiver households in rural Bangladesh. This study also tries to measure the impact of remittance on household level consumption and savings behavior in rural areas of Bangladesh.

\subsection{Study area and sampling design}

Khulna is the third largest division of Bangladesh which is situated in the south-west region of the country. Secondary data indicates that the rate of migration is comparatively higher in Rupsa upazila of the division. The upazila consists of nine unions. Among these nine unions, this study randomly selects one union (named Aijganti) for collecting primary data. A total of 10,369 families live in this union. The number of male and female population in the union is 22,353 and 22,005 respectively. Under the selected Aijganti union, six villages (named Aijganti, Razapur, Jogihati, Milky Diara, Shirganti and Diara) are randomly selected for collecting primary data. This study purposively selects 120 households as primary respondents to the study taking 10 households having migrants and 10 households having no-migrants from each of the selected six villages.

\subsection{Analytical framework}


The following two hypotheses are intended to address the objectives of this study:

$\mathrm{H}_{1}$ : Consumption (and savings) behavior of a remittance receiver household is significantly different from that of a remittance non-receiver household in rural Bangladesh;

$\mathrm{H}_{2}$ : Remittance has a significant impact on consumption (and savings) behavior of households in rural Bangladesh.

To achieve the objectives of this study, a path model (Figure 1) is proposed considering the variables of Table 1.

\begin{tabular}{|c|c|c|c|c|}
\hline \multicolumn{5}{|c|}{ Table 1: List of variables for path model analysis } \\
\hline Symbol & Variable Description & $\begin{array}{r}\text { Expected } \\
\text { Sign }\end{array}$ & Unit of Measurement & Reference / Literature \\
\hline MS & Migration status & + & $\begin{array}{r}\text { Dummy } \\
(1=\text { Yes, } 0=\text { No })\end{array}$ & Parinduri and Thaegavelu (2008) \\
\hline $\mathrm{RA}^{*}$ & Remittance amount & + & $\begin{array}{r}\text { US\$ per month (in } \\
\text { thousands) }\end{array}$ & Parinduri and Thaegavelu (2008) \\
\hline HI & Household income & + & $\begin{array}{r}\text { US\$ per month(in } \\
\text { thousands) }\end{array}$ & Parinduri and Thaegavelu (2008) \\
\hline FS & Family size & + & Number of members & Sinning (2008) \\
\hline LO & Loan amount & - & US\$ & Parinduri and Thaegavelu (2008) \\
\hline YA & Year of living in abroad & + & Years & Parinduri and Thaegavelu (2008) \\
\hline LA & Land amount & + & Decimal & Beaudouin (2006) \\
\hline $\mathrm{AV}$ & Total asset value & + & US\$ & Parinduri and Thaegavelu (2008) \\
\hline $\mathrm{AG}$ & Age of migrant & + & Years & Sinning (2008) \\
\hline EL & $\begin{array}{l}\text { Educational level of } \\
\text { migrant }\end{array}$ & + & Years of schooling & Parinduri and Thaegavelu (2008) \\
\hline
\end{tabular}

Figure 1: Proposed path model

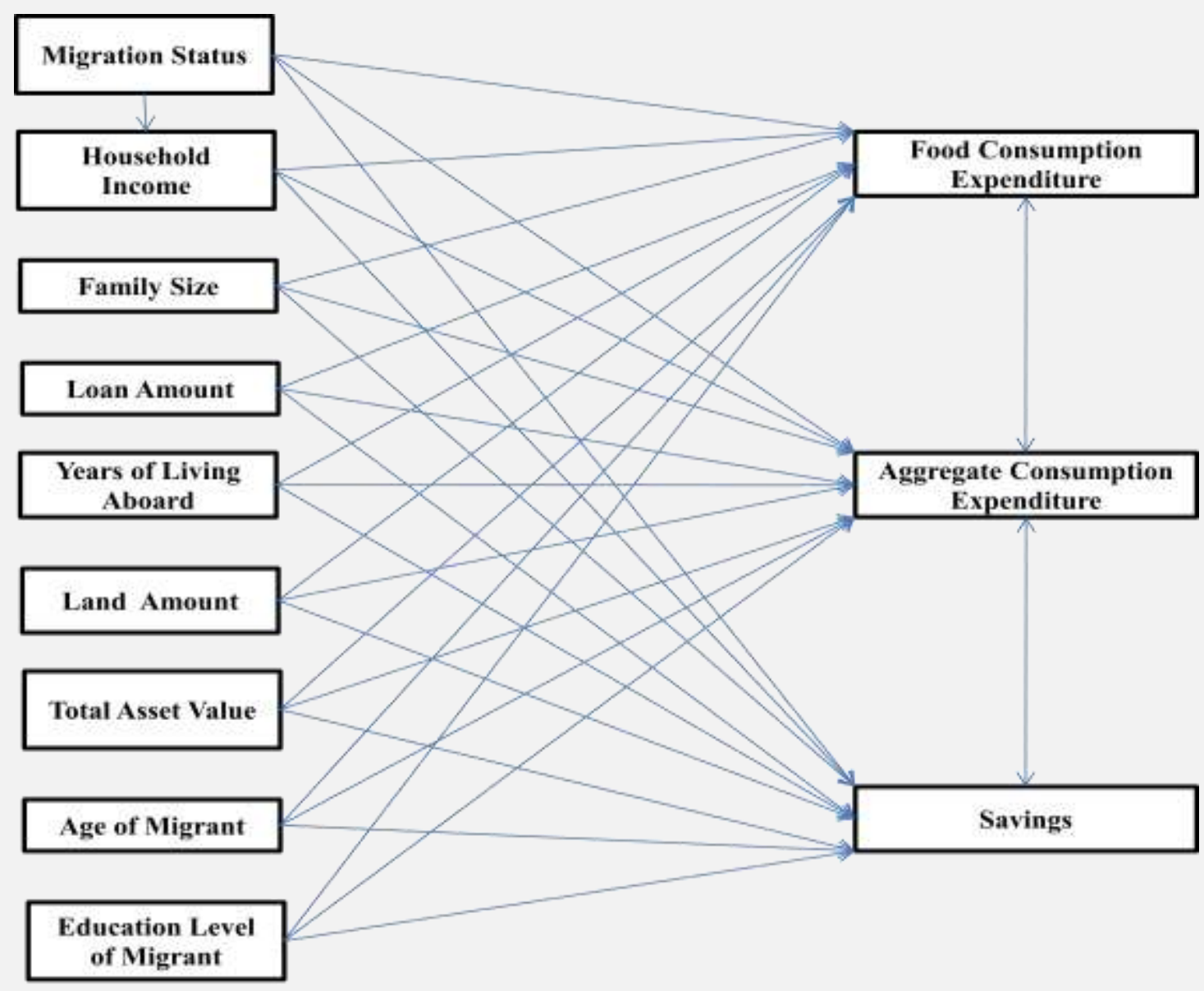




\section{Source: Authors' Compilation}

Using MPLUS software (Muthen \& Muthen, 2007), the proposed path model analysis with structural equation modeling (SEM) methodology is accomplished in this study. The insignificant paths are dropped from the proposed analysis. Possible significant correlations among the exogenous measures and also among the endogenous measures are considered in estimating the significant standardized path coefficients.

Path analysis is an alternative approach to regression analysis. It is a powerful, flexible and comprehensive technique for investigating relationships between measured variables. A path model analysis requires specification of a model based on theory and research. It is a multivariate technique incorporating measured variables. It is a statistical methodology for representing, estimating and testing a theoretical network of linear relations between variables (Rigdon, 1998). It tests hypothesized patterns of directional and non-directional relationships among a set of observed variables (MacCallum \& Austin, 2000). That is, a path model analysis helps to understand the patterns of correlation/covariance among a set of variables and to explain as much of their variance as possible with the model specified (Kline, 1998).

\subsection{Result and discussion}

People go to abroad from home country for searching better life and employment. Their remittance is an important source of development for the home country. Table 2 describes the descriptive statistics of the migrants. The Table demonstrates that a significant number of migrants chose Middle East for their migration destination. The number of migrants choosing Europe and Africa as migration destination is very insignificant. More than two-third of the surveyed migrants is educated having ten or more years schooling experience. None of them are illiterate. About two-third of the surveyed migrants are doing jobs, while only less than ten per cent of the migrants are engaged in business. Most of the surveyed migrants have been staying abroad for more than three years. Only about one-fifth of them are recent migrants having less than three years migration experience. About one-third of the migrants manage the initial migration cost from family members and relatives and another one-fourth manage the cost from own sources.

\begin{tabular}{|c|c|c|c|}
\hline \multicolumn{4}{|c|}{ Table 2: Information of migrants } \\
\hline Category & Description & Number of Migrants & Percent (\%) \\
\hline \multirow{5}{*}{ Migration Destination } & South Asia & 24 & 40 \\
\hline & Middle East & 26 & 43 \\
\hline & Europe & 6 & 10 \\
\hline & Africa & 4 & 7 \\
\hline & All & 60 & 100 \\
\hline \multirow{5}{*}{$\begin{array}{l}\text { Educational } \\
\text { Qualification of } \\
\text { Migrants }\end{array}$} & Below Class 5 & 0 & 0 \\
\hline & Class 5-9 & 19 & 32 \\
\hline & Class 10 (S.S.C) & 16 & 26 \\
\hline & Above Class 10 & 25 & 42 \\
\hline & All & 60 & 100 \\
\hline \multirow{6}{*}{ Profession of Migrants } & Business & 5 & 8 \\
\hline & Job & 40 & 67 \\
\hline & Day Labor & 4 & 67 \\
\hline & Servant & 5 & 8 \\
\hline & Others & 6 & 10 \\
\hline & All & 60 & 100 \\
\hline \multirow{5}{*}{ Length of Migration } & Below 3 Years & 12 & 20 \\
\hline & 3-6 Years & 22 & 37 \\
\hline & 7-10 Years & 22 & 37 \\
\hline & Above 10 Years & 4 & 6 \\
\hline & All & 60 & 100 \\
\hline \multirow{6}{*}{$\begin{array}{l}\text { Source of Migration } \\
\text { Cost }\end{array}$} & Own Sources & 15 & 25 \\
\hline & Family Members and Relatives & 19 & 32 \\
\hline & Bank and NGOs & 9 & 15 \\
\hline & Co-operative Society & 6 & 10 \\
\hline & Asset Selling & 11 & 18 \\
\hline & All & 60 & 100 \\
\hline
\end{tabular}

Source: Field Survey, 2013;

N.B.: The sum may not add to total due the rounding error. 


\subsection{Remittance, expenditure and savings pattern of the surveyed households}

The primary data indicate that about one-third of the remittance receiver households receive more than 300 US\$ per month as remittance on average and for another one-third households, the figure is 101-200 US\$ remittance per month on average. The number of less than 100 US\$ remittance receiving households is insignificant. The average remittance amount for the surveyed households is 358 US\$ per month (Table 3).

Table 3: Remittance, expenditure and savings pattern of households

\begin{tabular}{|c|c|c|c|c|c|c|}
\hline Criteria & $\begin{array}{r}\text { Range } \\
\text { (US\$/Month) }\end{array}$ & $\begin{array}{r}\text { Frequency } \\
(\mathrm{N})\end{array}$ & $\begin{array}{r}\text { Percent } \\
\text { (\%) }\end{array}$ & $\begin{array}{l}\text { Mean } \\
\text { (US\$) }\end{array}$ & $\begin{array}{r}\text { Minimum } \\
\text { (US\$) }\end{array}$ & $\begin{array}{r}\text { Maximum } \\
\text { (US\$) }\end{array}$ \\
\hline \multirow{7}{*}{ Remittance Inflow } & $\leq 100$ & 4 & 7 & 94 & 88 & 100 \\
\hline & $101-200$ & 23 & 38 & 160 & 113 & 188 \\
\hline & $201-300$ & 11 & 18 & 255 & 213 & 300 \\
\hline & $301-400$ & 10 & 17 & 325 & 313 & 375 \\
\hline & $401-500$ & 6 & 10 & 448 & 438 & 500 \\
\hline & $>500$ & 6 & 10 & 1,448 & 563 & 3,750 \\
\hline & All & 60 & 100 & 358 & 88 & 3,750 \\
\hline \multirow{5}{*}{$\begin{array}{l}\text { Monthly Food Expenditure } \\
\text { of Remittance Receiver } \\
\text { Household }\end{array}$} & $\leq 100$ & 20 & 34 & 83 & 50 & 100 \\
\hline & $101-200$ & 27 & 45 & 201 & 113 & 188 \\
\hline & $201-300$ & 11 & 18 & 243 & 206 & 275 \\
\hline & $>300$ & 2 & 3 & 344 & 313 & 375 \\
\hline & All & 60 & 100 & 154 & 50 & 375 \\
\hline \multirow{5}{*}{$\begin{array}{l}\text { Monthly Food Expenditure } \\
\text { of Remittance Non- } \\
\text { Receiver Household }\end{array}$} & $\leq 100$ & 26 & 43 & 82 & 50 & 100 \\
\hline & $101-200$ & 29 & 49 & 149 & 106 & 200 \\
\hline & $201-300$ & 5 & 8 & 224 & 213 & 238 \\
\hline & $>300$ & 0 & 0 & 0 & 0 & 0 \\
\hline & All & 60 & 100 & 126 & 50 & 238 \\
\hline \multirow{5}{*}{$\begin{array}{l}\text { Monthly } \\
\text { Consumption }\end{array} \begin{array}{r}\text { Aggregate } \\
\text { of Remitture } \\
\text { Household }\end{array}$} & $\leq 100$ & 6 & 10 & 80 & 63 & 94 \\
\hline & $101-200$ & 25 & 42 & 158 & 106 & 194 \\
\hline & $201-300$ & 18 & 30 & 244 & 213 & 300 \\
\hline & $>300$ & 11 & 18 & 360 & 306 & 563 \\
\hline & All & 60 & 100 & 213 & 63 & 563 \\
\hline \multirow{5}{*}{$\begin{array}{lr}\text { Monthly } & \text { Aggregate } \\
\text { Consumption Expenditure } \\
\text { of Remittance } & \text { Non- } \\
\text { Receiver Household } & \end{array}$} & $\leq 100$ & 7 & 12 & 86 & 69 & 94 \\
\hline & $101-200$ & 32 & 53 & 145 & 103 & 194 \\
\hline & $201-300$ & 16 & 27 & 233 & 206 & 283 \\
\hline & $>300$ & 5 & 8 & 358 & 331 & 428 \\
\hline & All & 60 & 100 & 181 & 69 & 428 \\
\hline \multirow{6}{*}{$\begin{array}{lr}\text { Monthly } & \text { Savings of } \\
\text { Remittance } & \text { Receiver } \\
\text { Household } & \end{array}$} & $\leq 30$ & 16 & 27 & 11 & 0 & 30 \\
\hline & $31-60$ & 23 & 38 & 46 & 31 & 58 \\
\hline & $61-90$ & 19 & 31 & 73 & 63 & 88 \\
\hline & $91-120$ & 1 & 2 & 113 & 113 & 113 \\
\hline & $>121$ & 1 & 2 & 188 & 188 & 188 \\
\hline & All & 60 & 100 & 48 & 0 & 188 \\
\hline \multirow{6}{*}{$\begin{array}{ll}\text { Monthly Savings } & \text { of Non- } \\
\text { Remittance } & \text { Receiver } \\
\text { Household } & \end{array}$} & $\leq 30$ & 25 & 42 & 18 & 0 & 30 \\
\hline & $31-60$ & 26 & 43 & 38 & 31 & 56 \\
\hline & $61-90$ & 5 & 8 & 69 & 63 & 75 \\
\hline & $91-120$ & 1 & 2 & 100 & 100 & 100 \\
\hline & $>121$ & 3 & 5 & 100 & 125 & 150 \\
\hline & All & 60 & 100 & 38 & 0 & 150 \\
\hline
\end{tabular}

Source: Field Survey, 2013

N.B.: The figures are rounded; The sum may not add to total due the rounding error.

Field level food expenditure data indicate that monthly average food expenditure for most of the surveyed remittance receiver households (about 78 per cent) is less than 200 US\$ per month on average. However, the amount is comparatively lower for the remittance non-receiver households. More than 40 per cent of the remittance non-receiver households spend less than 100 US\$ per month on average for food expenditure.

About half of the remittance receiver households' monthly average aggregate consumption expenditure is less than 200 US\$, whereas the corresponding data for remittance non-receiver households is about two-third. 
About 60 per cent of the remittance receiver households' savings is less than 60 US\$ on average per month, while the corresponding data is about 85 per cent for remittance non-receiver households.

\subsection{Expenditure and savings differences of the surveyed households}

This study attempts to check whether there are significant differences in consumption and savings pattern between remittance receiver and non-receiver households in rural Bangladesh. The authors try to compare the mean difference between the two groups through testing the first hypothesis of this study. The analysis results are portrayed in Table 4. The test results indicate that the remittance receiver households monthly food consumption expenditure is on average about 28 US\$ higher than that of remittance non-receiver households in the study area and the said difference is statistically significant at 5 per cent level of significance.

Table 4: Expenditure and savings differences

\begin{tabular}{|c|c|c|c|c|}
\hline Variable & Respondents & Observation & $\begin{array}{r}\text { Mean Value } \\
\text { (US\$/Month) }\end{array}$ & $\begin{array}{r}\text { Standard } \\
\text { Error }\end{array}$ \\
\hline \multirow{3}{*}{$\begin{array}{l}\text { Food } \\
\text { Consumption }\end{array}$} & Remittance Receiver Households & 60 & 154 & 9 \\
\hline & Non-Receiver Households & 60 & 126 & 6 \\
\hline & Difference & - & $28 * *$ & 11 \\
\hline \multirow{3}{*}{$\begin{array}{l}\text { Aggregate } \\
\text { Consumption }\end{array}$} & Remittance Receiver Households & 60 & 213 & 12 \\
\hline & Non-Receiver Households & 60 & 181 & 10 \\
\hline & Difference & - & $32^{* *}$ & 16 \\
\hline \multirow{3}{*}{ Savings } & Remittance Receiver Households & 60 & 48 & 4 \\
\hline & Non-Receiver Households & 60 & 38 & 4 \\
\hline & Difference & - & $10^{*}$ & 6 \\
\hline
\end{tabular}

Source: Authors' Compilation

N.B.: ${ }^{* * *} \mathrm{p}<0.01,{ }^{* *} \mathrm{p}<0.05,^{*} \mathrm{p}<0.1$; The figures are rounded.

The monthly aggregate consumption expenditure (including both food and non-food expenditures) of the remittance receiver households is on average about 32 US\$ higher than that of remittance non-receiver households in the study area and the said difference is statistically significant at 5 per cent level of significance. In addition to expenditure, the monthly savings of the remittance receiver households is on average about 10 US\$ higher than that of remittance non-receiver households and the said difference is statistically significant at 10 per cent level of significance (Table 4).

\subsection{Impact of remittance on expenditure and savings}

The second hypothesis of this study is to check whether there is any significant impact of remittance on expenditure and savings of the households in the rural areas of Bangladesh. Since, multicollinearity is a common phenomenon in this type of social research, a pair-wise correlation analysis among the explanatory variables is performed to check how strongly the variables are correlated. The estimated correlation coefficients are reported in Table 5. The results indicate the presence of high multicollinearity in some cases. A multiple OLS regression analysis in presence of high multicollinearity, as in this case, might not provide correct standard error of the parameter estimates. Therefore, this study attempts to run linear structural equation modeling approach to evaluate the second hypothesis of this study.

\begin{tabular}{lrrrrrrrrr}
\hline \multicolumn{8}{c}{ Table 5: Correlation matrix of explanatory variables } \\
\hline Variable & MS & HI & FM & LO & YA & LA & AV & AG & EL \\
\hline MS & 1.00 & & & & & & & & \\
HI & $-0.28^{* * *}$ & 1.00 & & & & & & & \\
FM & 0.02 & $0.39^{* * *}$ & 1.00 & & & & & & \\
LO & 0.05 & 0.02 & $0.16^{*}$ & 1.00 & & & & & \\
YA & $0.73^{* * *}$ & $-0.19^{* *}$ & 0.04 & 0.05 & 1.00 & & & & \\
LA & $0.18^{*}$ & 0.06 & -0.05 & -0.05 & 0.08 & 1.00 & & & \\
AV & $-0.44^{* * *}$ & $0.48^{* * *}$ & $0.20^{* *}$ & $0.18^{*}$ & $-0.30^{* * *}$ & $0.16^{*}$ & 1.00 & & \\
AG & $-0.61^{* * *}$ & $0.17^{*}$ & $0.16^{*}$ & 0.04 & $-0.27^{* * *}$ & $-0.16^{*}$ & $0.39^{* * *}$ & 1.00 & \\
EL & $0.16^{*}$ & 0.00 & -0.02 & -0.05 & $0.20^{* *}$ & 0.15 & 0.11 & -0.10 & 1.00 \\
\hline
\end{tabular}


This study uses Mplus software to estimate the path model. This model gradually eliminates the insignificant explanatory variables and finally provides standardized coefficients for the significant explanatory variables. In addition to considering the multicollinearity among explanatory variables, this model also accounts the multicollinearity among the considered dependent variables. The estimation results are reported in Figure 2.

Figure 2: Path model estimation results

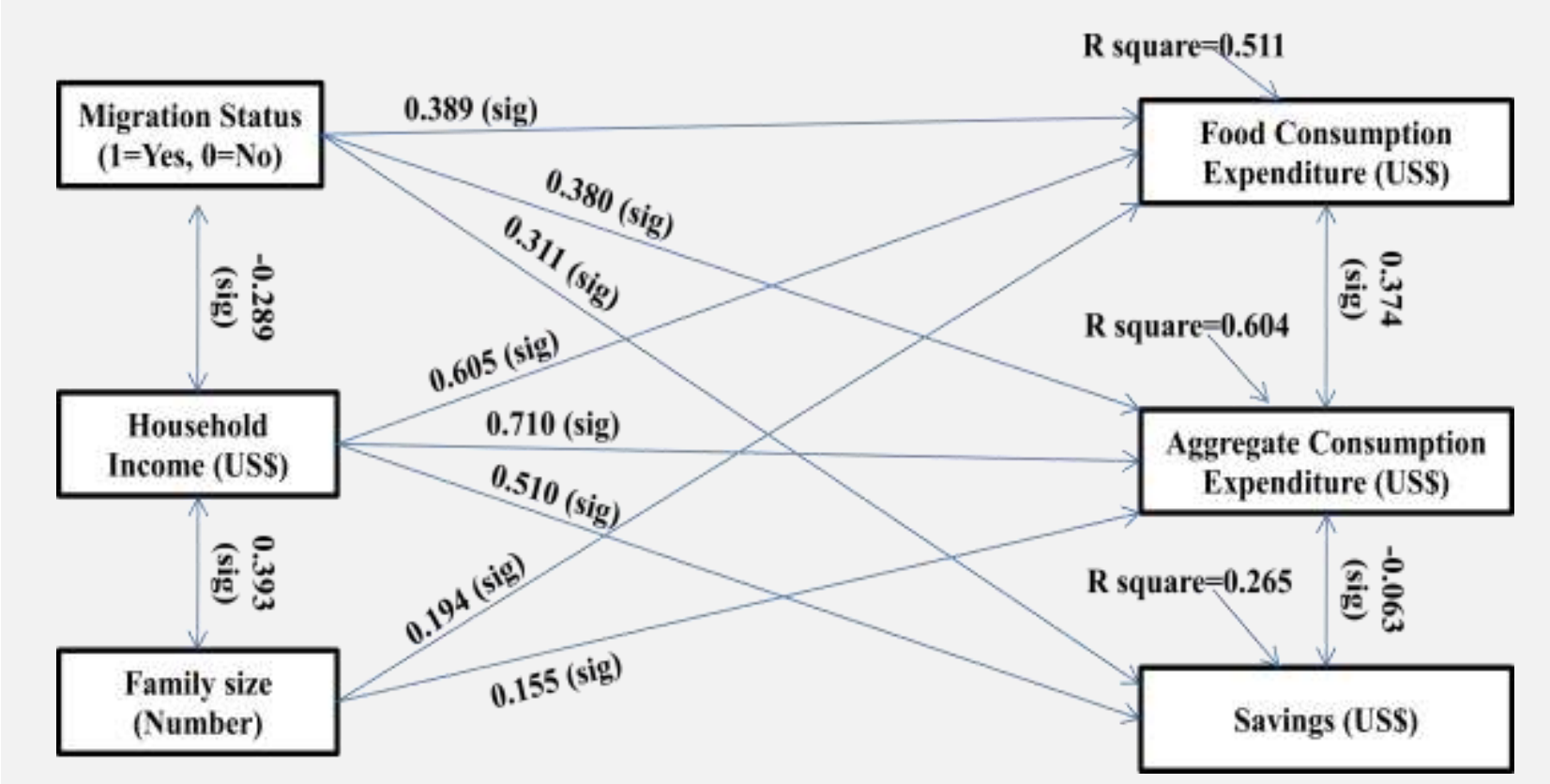

Source: Authors' Compilation

N.B.: $\mathrm{p}<0.01$; The vertical direction (two-way arrow) indicates correlation, where as the horizontal direction (one-way arrow) indicates the estimated standardized regression coefficients.

Based on the literature, this study starts with nine explanatory variables. However, the path model reduces it to three only (Figure 2) through step by step elimination of insignificant variables. The results indicate a moderate negative significant correlation between migration status and household income, and a moderate positive significant correlation between household income and family size, the explanatory variables of the model. Similarly, it finds a moderate positive significant correlation between food consumption and aggregate consumption, and a low negative significant correlation between aggregate consumption and savings, the dependent variables of the path model. All these correlations are in line with the expectation as per the prevailing literature.

The standardized regression coefficients of the estimated path model are also in line with the expectation as per the literature. For example, the results indicate that having migrants in a family significantly and positively influences the food consumption of the family. The other two explanatory variables, namely household income and family member also positively and significantly influence food consumption expenditure. However, among these three explanatory variables, the influence of household income is the strongest followed by migration status and family size respectively $(0.605>0.389>0.194)$. The corresponding $\mathrm{R}^{2}$ value is also high, 0.511 .

Similarly, the impacts of migration status in addition to household income and family member on aggregate consumption are positive and significant at 1 per cent level of significance. However, among these three explanatory variables, the influence of household income is the strongest followed by migration status and family size respectively $(0.710>0.380>0.155)$. The corresponding $\mathrm{R}^{2}$ value is the highest, 0.604 .

However, the scenario is somewhat different in case of savings. The impact of a family size on savings is insignificant, whereas the impacts of having migrants and household income on savings are positive and statistically significant at 1 per cent level. The influence of household income is stronger in comparison with that of family size on savings $(0.510>0.311)$. Therefore, from the path model it may be concluded that migration has a significant positive impact on household consumption and savings, holding other influences constant.

Instead of considering migration as a dummy variable like Figure 2, if we consider it as a continuous variable through using the remittance amount data, the fitted path model is similar to Figure 3. 
Figure 3: Fitted significant model for the migrants

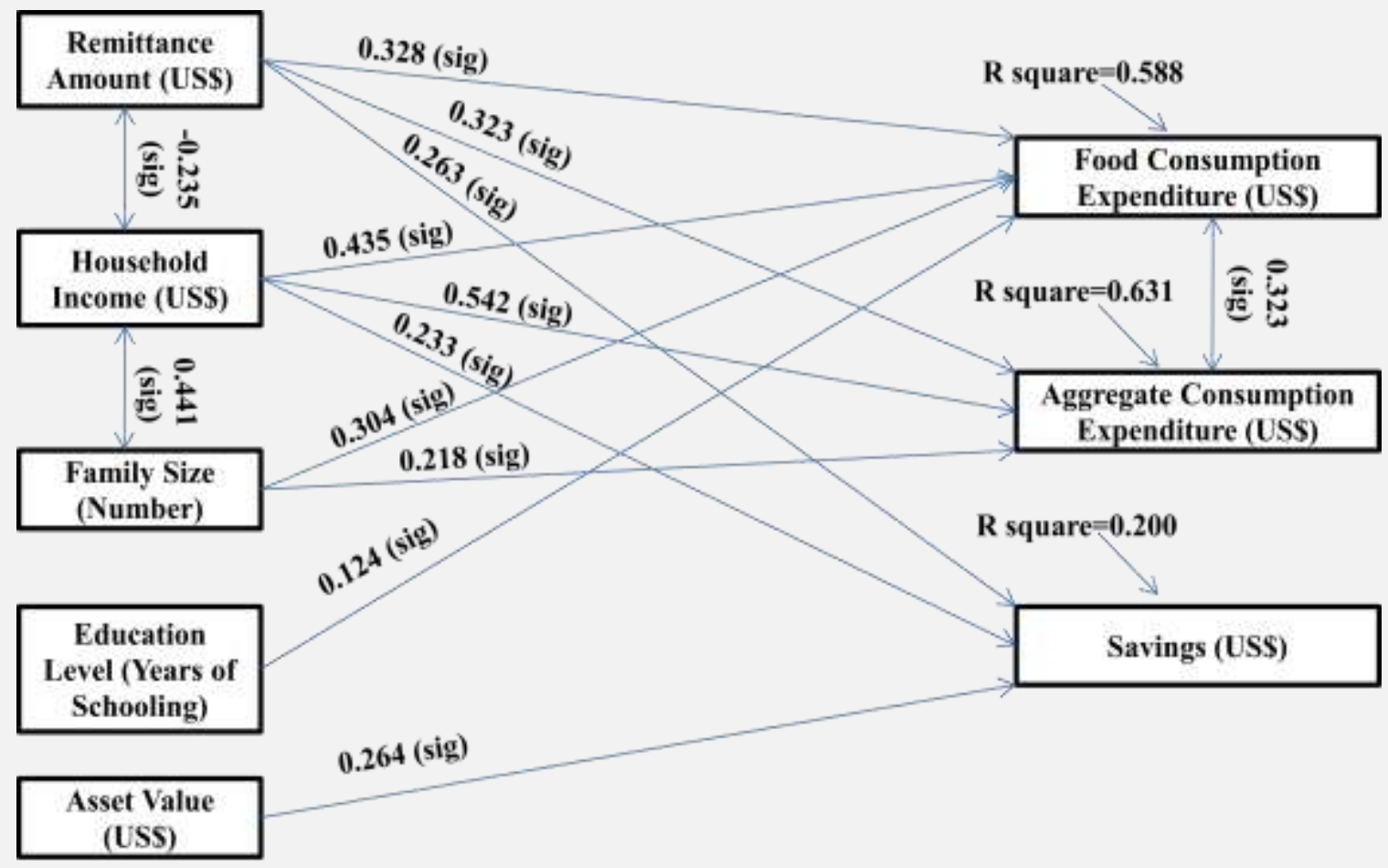

Source: Authors' Compilation

\subsection{Concluding remarks}

Remittance is an important tool for economic development of a country like Bangladesh. This study firstly tries to trace out the remittance inflow in the rural areas of Bangladesh through collecting primary data. The study findings indicate that a remittance receiving household receives 358 US\$ per month on average as remittance in the study area. A majority of the remittance senders are working in the Middle East followed by Asia. Most of the migrants are educated and doing jobs instead of engaging themselves in risky business activities. A majority of them have been staying abroad for a comparatively longer time period.

Secondly, this study tries to calculate the differences in consumption and savings behavior between remittance receiver and non-receiver households in rural Bangladesh. The study findings indicate that a remittance nonreceiver household's monthly food consumptions expenditure is 126 US\$ on average, while it is 154 US\$ for a remittance receiver household and the said difference of 28 US\$ per month per family is statistically significant at 5 per cent level of significance. The monthly aggregate consumption expenditure of a remittance receiving household is on average 32 US\$ higher than that of a remittance non-receiver household and the said difference is statistically significant at 5 per cent level of significance. Similarly, the savings is also significantly higher for the remittance receiving households, on average 10 US\$ per household per month.

Thirdly, this study tries to figure out the influence of remittance on consumption and savings behavior of the households living in rural areas of Bangladesh. The path model analysis findings indicate that remittance has a statistically significant positive impact on household consumption, expenditure and savings, though the influence is not as strong as household income.

Therefore, this study concludes that remittance has a significant positive impact on consumption and savings behavior among the surveyed households in the rural areas of Bangladesh. Accordingly, it suggests for encouraging remittance inflow for overall socio-economic development. However, for enhancing the robustness and for generalization of the study findings, future studies on this research topic may highlight on randomness in the sample selection process with wider sample and area coverage.

\section{References}

Adams, R.H., \& Cuecuecha, A. (2010). Remittances, Household Expenditure and Investment in Guatemala. World Development, 38 (11), 1626-1641. http://dx.doi.org/10.1016/j.worlddev.2010.03.003 
Adams, R.H., Cuecuecha, A., \& Page, J. (2008). Remittances, Consumption and Investment in Ghana (Working Paper, No. 4515). Washington DC: The World Bank (WB). Retrieved from:http://wwwwds.worldbank.org/servlet/WDSContentServer/WDSP/IB/2008/02/12/000158349_20 080212092546/Rendered/PDF/wps4515.pdf (Accessed 10 April 2013). http://dx.doi.org/10.1596/18139450-4515.

Ahmed, H.A., \& Uddin, M.G.S. (2009). Export, Imports, Remittance and Growth in Bangladesh: An Empirical Analysis. Trade and Development Review, 2(2), 79-92.

Azad, A.K. (2003). Importance of Migrant's Remittance for Bangladesh Economy. Paper presented at the International Conference on Migrant Remittance (ICMR), International Migration Policy Programme, London, England. Retrieved from: http://siteresources.worldbank.org/INTTOPCONF3/Resources/ 1588024115254209834/O_A.Azad_Importance0_of_Migrants_Remittance_for_Bangladesh_Economy.pdf (Accessed 21 June 2013).

Bangladesh Bureau of Statistics (BBS, 2011). Statistical Year Book of Bangladesh 2011. Ministry of Planning, Government of the Peoples Republic of Bangladesh, Dhaka, Bangladesh.

Barajas, A., Chami, R., Fullenkamp, C., Gapen, M., \& Montiel, P. (2009). Do Workers' Remittances Promote Economic Growth? (Working Paper No. 9). Washington DC: International Monetary Fund (IMF). Retrieved from: http://www.iadb.org/intal/intalcdi/pe/2009/03935.pdf (Accessed 10 April 2013).

Barua, S., Majumder, M.A., \& Akhtaruzzaman, M. (2005). Determinants of Workers' Remittances in Bangladesh: An Empirical Study. Bangladesh Bank, Dhaka.

Beaudouin, P.Y. (2006, May). Economic Impact of Migration on a Rural Area in Bangladesh. Paper presented at the AFSE seminar in University of Paris, France.

Bruyn, T.D., \& Kuddus, U. (2005). Dynamics of Remittance Utilization in Bangladesh (Working Paper No. 18). Switzerland: International Organization for Migration (IMO). Retrieved form: http: //basug.nl/uploads/files/20060422_P39_TDB_Dynamics_pdf (Accessed 1 June 2013).

Castaldo, A., \& Reilly, B. (2007). Do Migrant Remittances Affect the Consumption Patterns of Albanian Households?, South-Eastern Europe Journal of Economics, 1, 25-54.

Chowdhury, K.R., Hamid, F., \& Chatterjee, D.D. (2010). Remittance as a Tool of Economic Development: Bangladesh Perspective. Bangladesh Research Publications Journal, 4(3), 286-296.

El-Sakka, M.I.T. (2004). Migrant Workers' Remittances and Macroeconomic Policy in Jordan. Kuwait University, Kuwait.

Ghosh, B. (2006). Migrant's Remittances and Development (Working Paper). Switzerland: International Organization for Migration (IMO). Retrieved form: http://bimal_ghosh_d2915556-f851-de11-afac001cc477ec70_2.pdf (Accessed 2 April 2013).

Hasan, M.M. (2004). The Macroeconomic Determinants of Remittances in Bangladesh. Institute of Microfinance, Dhaka.

International Fund for Agricultural Development (IFAD, 2007). Remittance Forum: Asia and Oceania. United Nations Development Groups, Rome, Italy.

Kabir, M.Z., Rashid, M.M., Hossain, M.M., Rashid, M.A., \& Amin, M.H.A. (2011). Global Financial Crisis and Its Impact on Overseas Employment and International Remittance of Bangladesh. Bangladesh Research Publications Journal, 6(1), 111-119.

Kline, R.B. (1998). Principles and Practice of Structural Equation Modeling. New York: The Guilford Press.

MacCallum, R.C., \& Austin, J.T. (2000). Applications of Structural Equation Modeling in Psychological Research. Annual Review of Psychology, 51, 201-226. http://dx.doi.org/10.1146/annurev.psych.51.1.201

Mamun, K.A., \& Nath, H.K. (2010). Workers' Migration and Remittances in Bangladesh (Working Paper No. 2). USA: Department of Economics and Finance. Retrieved form: http://www.shsu.edu/tcq001/paper files/wp10-02 paper.pdf (Accessed 1 April 2013).

Mellyn, K. (2003). Worker Remittances as a Development Tool Opportunity for the Philippines. Asian Development Bank, Philippines.

Muthen, L.K., \& Muthen, B. O. (2007). Mplus User's Guide (4th ed.). Los Angeles: Muthen\&Muthen.

Osili, U.O. (2006). Remittances and Savings from International Migration: Theory and Evidence Using a Matched Sample. Journal of Development Economics, 83(1), 446-465.

Parinduri, R.A., \& Thangavelu, S.M. (2008). Remittance and Migrant Households Consumption and Saving Patterns: Evidence from Indonesia (Research Paper No. 8). Nottingham University Business School Malaysia Campus, Malaysia. Retrieved from: http://ssrn.com/abstract=1146366.pdf (Accessed 5 June 2013).

Rigdon, E.E. (1998). Structural Equation Modeling. In G.A. Marcoulides (Ed.), Modern Methods for Business Research (pp. 251-294). Mahwah, NJ: Lawrence Erlbaum Associates. http://dx.doi.org/10.1080/10705519809540091

Siddiqui, T. (2004). Efficiency of Migrant Workers' Remittance: The Bangladesh Case. Asian Development Bank, Manila. 
Sinning, M.G. (2008). Determinants of Savings and Remittances: Empirical Evidence from Immigrants to Germany (Occasional Paper). Social Policy Evaluation, Analysis and Research Centre (SPEAR), Australia. Retrieved from: http://mbc.metropolis.net/assets/uploads/files/Sinning.pdf (Accessed 13 March 2013).

Udah, E.B. (2011). Remittances, Human Capital and Economic Performance in Nigeria. Journal of Sustainable Development in Africa, 13(4), 300-318.

Unnayan Onneshan (UO, 2012). Bangladesh Economic Update Remittance 2012. Dhaka, Bangladesh, 3-7. 